\title{
IMPLEMENTASI LESSON STUDY UNTUK MENINGKATKAN KINERJA DOSEN MATEMATIKA STMIK DUTA BANGSA SURAKARTA
}

\author{
Anisatul Farida \\ Teknik Informatika, STMIK Duta Bangsa \\ email: vava_cipa@yahoo.com
}

\begin{abstract}
Abstrak.
Tujuan penelitian ini adalah meningkatkan kinerja dosen matematika pada proses perkuliahan melalui kegiatan lesson study dalam pelaksanaan pembelajaran. Penelitian ini merupakan penelitian tindakan yaitu menerapkan lesson study untuk meningkatkan kinerja dosen matematika. Metode pengumpulan data yaitu observasi terhadap dosen model dalam perkuliahan, metode angket dan wawancara mendalam. Penelitian ini dilaksanakan di sebuah Sekolah Tinggi Manajemen dan Ilmu Komputer di Surakarta. Pelaksanaan penelitian dimulai bulan Oktober - November 2016 sebanyak dua siklus penelitian. Subjek dalam penelitian ini adalah 4 dosen dengan keahlian matematika. Instrumen yang digunakan dalam penelitian ini adalah lembar observasi, pedoman wawancara dan angket tertutup tentang respon mahasiswa setelah dosen mengajar. Metode analisis data menggunakan pendekatan proses siklik yakni data dianalisis sejak tindakan pembelajaran dilaksanakan (sejak dari plan-do-see), dikembangkan selama proses pembelajaran berlangsung sampai diperoleh pembelajaran yang berkualitas/professional. Metode analisis data ini terdiri dari tiga langkah yaitu; reduksi data, penyajian data dan verifikasi, dan penarikan kesimpulan. Hasil penelitian menunjukkan bahwa dengan implementasi kegiatan lesson study dapat meningkatkan kinerja dosen matematika pada proses perkuliahan.
\end{abstract}

Kata Kunci: Lesson study, Kinerja Dosen, matematika

\begin{abstract}
The purposes of this study is to improve performance maths lecturer to the process of them through the lesson study in the implementation of learning. It used research action. It is to apply lesson study to improve their performance maths lecturer. Data collection method by observation of lecturers model at the lesson, questionnaires and in-depth interview. This study was located at High School Management and Computer Science in Surakarta. It was start from Oktober - November 2016 by two cycle research. Subject at this study are 4 lecturer expertise on mathematics. Instrument of this study are observation sheet, interview guidelines and close questionnaires about students response after lecturers teaching. The method of analysis data using approach cyclic process is analyzed data since the act of learning implemented ( from plan-do-see), developed during learning lasted until obtained learning / professional quality. Data analysis methods it consists of three ways namely; reduction of data, presentation of data and verification, inference. The result showed that the implementation of the lesson study can improve performance maths lecturer at learning process.
\end{abstract}

Keywords: Lesson study, Lecturer performance, mathematics

\section{PENDAHULUAN}

Data BAK (Biro Administrasi Akademik) tahun 2016, di STMIK (Sekolah Tinggi
Manajemen dan Ilmu Komputer) di Surakarta terdapat 6 dosen matematika dengan berbagai bidang keahlian. Matematika merupakan salah satu ilmu yang menjadi dasar 
perkuliahan di STMIK Duta Bangsa. Oleh karena itulah terdapat banyak dosen matematika dengan berbagai keahlian yang berbeda. Dari pernyataan tersebut terdapat beberapa penyebab rendahnya mutu perkuliahan di perguruan tinggi, sebagai berikut: 1) Pada umumnya para dosen bekerja sendirian dalam mempersiapkan dan melaksanakan perkuliahan. Apabila dosen tersebut inovatif dalam membelajarkan mahasiswa maka kreativitasnya tidak berimbas terhadap dosen lain karena tidak ada sharing di antara dosen tentang proses pembelajaran. Ketika dosen yang kreatif sudah tidak aktif lagi maka yang terjadi kreativitasnya hilang pula. 2) Pada umumnya tidak ada kolaborasi diantara dosen, padahal tidak ada perkuliahan yang sempurna, dan selalu ada celah untuk perbaikan, dan perbaikan ini akan lebih efektif kalau tercipta kolaborasi. Mindset dosen tersebut perlu diperbaiki agar dosen dapat berkolaborasi dan mau sharing dengan dosen lain serta terbuka untuk perbaikan perkuliahan. Pendekatan lesson study merupakan alternatif perbaikan mindset dosen dalam memperbaiki proses pembelajaran.

Selain itu akan banyak dosen yang tidak dapat beradaptasi dengan perkembangan jaman dan tidak kreatif dalam membelajarkan mahasiswa. Sementara perkembangan teknologi begitu cepat terutama teknologi informasi dan dunia maya yang terdapat di dalamnya dapat menggoda mahasiswa untuk tidak belajar. Apalagi dosen tersebut tidak dapat beradaptasi dengan perkembangan teknologi maka metode/strategi pembelajaran yang monoton tidak mampu bersaing dengan godaan dunia dan tidak mampu menarik perhatian mahasiswa untuk belajar, serta tidak menantang mahasiswa untuk berpikir.

Dari berbagai alasan yang dikemukakan di atas maka perlu adanya lesson study antar dosen. Tujuan penelitian ini adalah untuk mendeskripsikan bahwa lesson study dapat meningkatkan kinerja dosen. Lesson study yang dilakukan dikolaborasikan dengan kegiatan Penelitian Tindakan Kelas (Action Reseach) yang meliputi tahapan Plan, Do, See. Penelitian ini dirancang untuk dilaksanakan bersiklus, adapun setiap siklusnya meliputi perencanaan (plan), pelaksanaan (do) dan refleksi (see).

Lesson study adalah suatu model pembinaan profesi pendidik melalui pengkajian pembelajaran kolaboratif dan berkelanjutan berlandaskan prinsip-prinsip kolegalitas dan mutual learning untuk membangun komunitas belajar (Hendayana: 2006). Slamet Mulyana (2007) dalam Madawati (2015) memberikan rumusan tentang Lesson Study sebagai salah satu model pembinaan profesi pendidik melalui 
pengkajian pembelajaran secara kolaboratif dan berkelanjutan berlandaskan pada prinsippsrinsip kolegalitas dan mutual learning untuk membangun komunitas belajar. Sementara itu, Catherine Lewis (2002) dalam Madawati (2015) menyebutkan bahwa:

"lesson study is a simple idea. If you want to improve instruction, what could be more obvious than collaborating with fellow teachers to plan, observe, and reflect on lessons? While it may be a simple idea, lesson study is a complex process, supported by collaborative goal setting, careful data collection on student learning, and protocols that enable productive discussion of difficult issues".

Bill Cerbin \& Bryan Kopp dalam Madawati (2015) mengemukakan bahwa Lesson Study memiliki 4 (empat) tujuan utama, yaitu untuk: (1) memperoleh pemahaman yang lebih baik tentang bagaimana siswa belajar dan guru mengajar; (2) memperoleh hasil-hasil tertentu yang dapat dimanfaatkan oleh para guru lainnya, di luar peserta Lesson Study; (3) meningkatkan pembelajaran secara sistematis melalui inkuiri kolaboratif. (4) membangun sebuah pengetahuan pedagogis, dimana seorang guru dapat menimba pengetahuan dari guru lainnya. Melalui lesson study dosen matematika inilah diharapkan dapat meningkatkan kinerja dosen dan akhirnya berdampak pada kualitas pembelajaran dan mahasiswa.

\section{METODE PENELITIAN}

Penelitian ini merupakan penelitian tindakan yang terdiri dari 2 siklus dimana lesson study juga terdiri dari 2 siklus. Penelitian ini merupakan Penelitian Tindakan Kelas (Action Reseach) yang meliputi tahapan Plan, Do, See. Penelitian ini dirancang untuk dilaksanakan bersiklus, adapun setiap siklusnya meliputi perencanaan (plan), pelaksanaan (do) dan refleksi (see). Siklus lesson study diilustrasikan pada gambar di bawah ini:

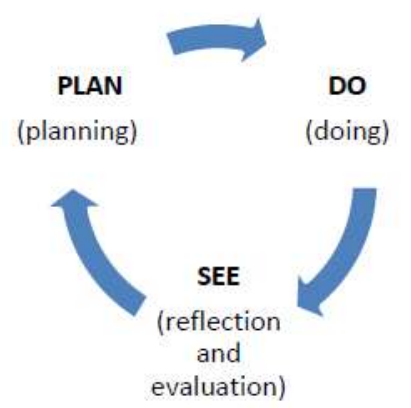

\section{Gambar 1. Siklus lesson study}

Metode pengumpulan data: observasi terhadap dosen model dalam perkuliahan, selain itu pengumpulan data juga menggunakan metode angket dan wawancara mendalam. Penelitian ini dilaksanakan di STMIK Duta Bangsa. Pelaksanaan penelitian dimulai bulan Oktober - November 2016. Subjek dalam penelitian ini adalah dosen dengan keahlian matematika di STMIK Duta Bangsa Surakarta yang berjumlah 4 orang. 
Waktu penelitian pada Semester Gasal Tahun Pelajaran 2016/2017.

Instrumen yang digunakan dalam penelitian ini adalah lembar observasi, pedoman wawancara dan angket tertutup tentang respon mahasiswa setelah dosen mengajar.

Metode analisis data menggunakan pendekatan proses siklik yakni data dianalisis sejak tindakan pembelajaran dilaksanakan (sejak dari plan-do-see), dikembangkan selama proses pembelajaran berlangsung sampai diperoleh pembelajaran yang berkualitas/professional, metode analisis data ini terdiri dari tiga alur yaitu; reduksi data, penyajian data, penarikan kesimpulan/ verifikasi (Miles dan Huberman,1992:1521).

Langkah-langkah analisis data ditunjukkan gambar 2 berikut.

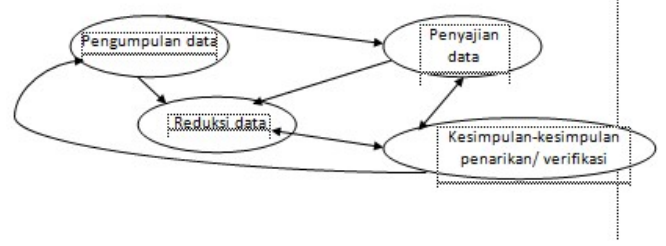

Gambar 2. Komponen analisis data Miles dan Huberman

\section{HASIL DAN PEMBAHASAN}

a. Siklus I

Kegiatan pada siklus I dimulai dengan perencanaan (plan), dimana dosen model menyampaikan perangkat pembelajaran, materi, dan rencana yang akan dilaksanakan di kelas. Pelaksanaan (do), dilaksanakan tanggal 17 Oktober 2016, 18 Oktober 2016, 20 Oktober 2016, dan 21 Oktober 2016. kegiatan selanjutnya adalah refleksi (see) dari pembelajaran yang telah dilaksanakan. Observer ini menyampaikan temuannya terkait dengan aktivitas belajar mahasiswa.

b. Siklus II

Kegiatan perencanaan (plan) diawali dengan menyampaikan rencana pembelajaran yang berdasarkan pada kekurangan dan perbaikan pada pertemuan pertama. Setelah plan selesai, kegiatan pembelajaran (do) dilaksanakan pada tanggal 24 Oktober 2016, 25 Oktober 2016, 26 Oktober 2016, dan 28 Oktober 2016. Kegiatan selanjutnya adalah refleksi (see) dari pembelajaran yang telah dilaksanakan. Apabila ada kelemahan selama pembelajaran akan dijadikan acuan perbaikan dan pembelajaran yang sudah sesuai akan digunakan sebagai pedoman untuk pembelajaran selanjutnya.

Berikut tabel hasil penelitian siklus I dan siklus II di bawah ini: 
Tabel 1. Hasil penelitian siklus I

\begin{tabular}{|l|l|l|l|l|l|}
\hline No & \multicolumn{1}{|c|}{ Indikator } & $\begin{array}{c}\text { DM } \\
\mathbf{1}\end{array}$ & $\begin{array}{c}\text { DM } \\
\mathbf{2}\end{array}$ & $\begin{array}{c}\text { DM } \\
\mathbf{3}\end{array}$ & $\begin{array}{c}\text { DM } \\
\mathbf{4}\end{array}$ \\
\hline 1. & Kelengkapan instrumen pembelajaran & 3 & 3 & 4 & 3 \\
\hline 2. & $\begin{array}{l}\text { Kempuan membuka dan pemberian } \\
\text { persepsi }\end{array}$ & 3 & 4 & 3 & 3 \\
\hline 3. & Kejelasan penyampaian materi & 4 & 4 & 3 & 3 \\
\hline 4. & $\begin{array}{l}\text { Penggunaan alat peraga dan media } \\
\text { pembelajaran }\end{array}$ & 3 & 3 & 4 & 3 \\
\hline 5. & $\begin{array}{l}\text { Fasilitator dalam pembelajaran dan } \\
\text { diskusi kelompok }\end{array}$ & 3 & 4 & 3 & 3 \\
\hline 6. & $\begin{array}{l}\text { Pengorganisasian mahasiswa dalam } \\
\text { kelompok }\end{array}$ & 3 & 4 & 4 & 3 \\
\hline 7. & Melakukan evaluasi proses & 3 & 3 & 4 & 3 \\
\hline 8. & Membuat ulasan dan kesimpulan & 4 & 3 & 3 & 4 \\
\hline 9. & Pemberian umpan balik dan pujian & 3 & 4 & 3 & 3 \\
\hline 10. & Pemberian tugas & 4 & 4 & 4 & 4 \\
\hline 11. & Kemampuan menutup pembelajar an & 3 & 3 & 4 & 3 \\
\hline 12. & Kemampuan pengorganisasian waktu & 3 & 4 & 4 & 3 \\
\hline 13. & $\begin{array}{l}\text { Kemampuan pemberian saran dari } \\
\text { orang lain }\end{array}$ & 3 & 4 & 3 & 3 \\
\hline 14. & $\begin{array}{l}\text { Kemampuan bekerjasama dengan } \\
\text { orang lain }\end{array}$ & 4 & 3 & 4 & 4 \\
\hline 15. & Semangat motivasi dalam bekerja & 4 & 3 & 4 & 4 \\
\hline
\end{tabular}

Tabel 2. Hasil penelitian siklus II

\begin{tabular}{|c|c|c|c|c|c|}
\hline No & Indikator & $\begin{array}{c}\mathrm{DM} \\
1\end{array}$ & $\begin{array}{c}\mathrm{DM} \\
2\end{array}$ & $\underset{3}{\mathrm{DM}}$ & $\mathrm{DM}$ \\
\hline 1. & Kelengkapan instrumen pembelajaran & 4 & 4 & 4 & 4 \\
\hline 2. & $\begin{array}{l}\text { Kempuan membuka dan pemberian } \\
\text { apersepsi }\end{array}$ & 4 & 4 & 4 & 4 \\
\hline 3. & Kejelasan penyampaian materi & 4 & 4 & 4 & 4 \\
\hline 4. & $\begin{array}{l}\text { Penggunaan alat peraga dan media } \\
\text { pembelajaran }\end{array}$ & 4 & 4 & 4 & 5 \\
\hline 5. & $\begin{array}{l}\text { Fasilitator dalam pembelajaran dan } \\
\text { diskusi kelompok }\end{array}$ & 4 & 4 & 4 & 4 \\
\hline 6. & $\begin{array}{l}\text { Pengorganisasian mahasiswa dalam } \\
\text { kelompok }\end{array}$ & 4 & 4 & 4 & 4 \\
\hline 7. & Melakukan evaluasi proses & 4 & 5 & 4 & 4 \\
\hline 8. & Membuat ulasan dan kesimpulan & 4 & 4 & 4 & 4 \\
\hline 9. & Pemberian umpan balik dan pujian & 4 & 4 & 4 & 4 \\
\hline 10. & Pemberian tugas & 4 & 4 & 4 & 4 \\
\hline 11. & Kemampuan menutup pembelajar an & 4 & 4 & 4 & 4 \\
\hline 12. & Kemampuan pengorganisasian waktu & 4 & 4 & 5 & 4 \\
\hline 13. & $\begin{array}{l}\text { Kemampuan pemberian saran dari } \\
\text { orang lain }\end{array}$ & 4 & 4 & 4 & 4 \\
\hline 14. & $\begin{array}{l}\text { Kemampuan bekerjasama dengan } \\
\text { orang lain }\end{array}$ & 4 & 4 & 5 & 4 \\
\hline 15. & Semangat motivasi dalam bekerja & 4 & 4 & 4 & 4 \\
\hline
\end{tabular}

Keterangan: DM: Dosen Model, 5) Sangat Baik, 4) Baik, 3) Cukup, 2) Sangat Kurang, 1) Kurang

Berdasarkan hasil penelitian yang dilaksanakan pada siklus I dan siklus II terdapat peningkatan kinerja dosen dalam melaksanakan perkuliahan. Hal tersebut menunjukkan bahwa penerapan lesson study dalam proses perkuliahan memberikan dampak yang sangat baik.

Dari hasil penelitian dan analisis data, pada bagian ini akan dilakukan pembahasan dengan didasari penelitian terdahulu yang sesuai dengan judul penelitian lesson study. Hasil siklus I menunjukkan kegiatan lesson study dimulai dari tahap plan, do, dan see. Dari ketiga tahap itu terjadi peningkatan kualitas pembelajaran dosen. Mahasiswapun antusias dengan pembelajaran yang diberikan dosen dibandingkan sebelum adanya lesson study. Hal ini sesuai dengan penelitian Padlurrahman \& Novianti (2015) yang menyatakan bahwa lesson study dapat meningkatkan kompetensi dosen. Pelaksanaan lesson study diperlihatkan pada gambar di bawah ini:

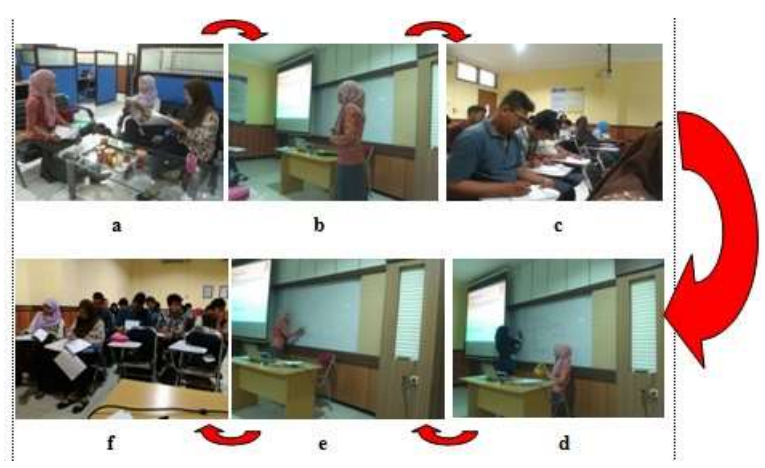

Gambar 3. Implementasi lesson study

Catatan:

$$
\begin{array}{ll}
\text { a } & \text { : kegiatan plan } \\
\text { b-e } & : \text { kegiatan do } \\
\mathrm{f} & \text { : kegiatan see }
\end{array}
$$

Peningkatan kualitas dosen dapat dilihat dari indikator kemampuan dosen antara lain mampu merencanakan pembelajaran, mengelola kelas, memilih materi dan alat evaluasi, memilih metode dan media pembelajaran, memanfaatkan teknologi 
informasi, dan memiliki sikap positif terhadap pembelajaran serta memiliki semangat kolegalitas yang tinggi. Pada penelitian ini juga mengalami peningkatan pada indikator-indikator yang terdapat pada tabel 1. Namun ada beberapa indikator yang skornya masih kurang yaitu pada kurangnya persiapan perangkat pembelajaran, penggunaan media pembelajaran, dan pengelolaan waktu. Selain itu, partisipasi dosen selama pelaksanaan lesson study menunjukkan tingkat partisipasi yang cukup baik seperti ikut serta dalam merencanakan pembelajaran, melaksanakan pembelajaran, dan mengevaluasi kegiatan pembelajaran.

Observer juga mengamati bahwa dengan adanya lesson study kemandirian belajar mahasiswa meningkat. Memang mahasiswa membutuhkan petunjuk awal dari dosen sebelum mengerjakan. Namun dengan petunjuk tersebut akhirnya mahasiswa mampu berdiskusi dan mengerjakan soal yang diberikan dosen dengan tepat. Hal ini sesuai dengan penelitian Nudji (2014) yang menyatakan bahwa lesson study dapat meningkatkan kemandirian belajar mahasiswa.

Penelitian Subadi (2015) juga mendukung penelitian ini. Di dalam penelitiannya menyatakan bahwa peningkatan kualitas perkuliahan dapat dilakukan dengan lesson study. Selain itu sistem peningkatan pembelajaran aktif, inovatif, kreatif bagi mahasiswa dengan perkuliahan berbasis lesson study modifikasi. Dari sinilah peneliti dalam melakukan lesson study, pada tahap plan dan see baik di siklus I maupun II melakukan sharing dengan dosen model bahwa lesson study modifikasi pada perkuliahan di STMIK Duta Bangsa dapat dilakukan dengan pembelajaran berbasis IT dan menghubungkan setiap materi dengan aplikasi komputer yang sesuai dengan materi perkuliahan.

Dari semua tahap lesson study yang dilakukan pada siklus I maupun siklus II, lesson study merupakan suatu cara yang efektif untuk meningkatkan kualitas pembelajaran yang dilakukan dosen dan aktivitas belajar mahasiswa. Selain itu, apabila lesson study dirancang dengan sebaik-baiknya maka ini merupakan kegiatan yang akan menjadikan dosen menjadi profesioal dan inovatif. Inovatif disini pada pemilihan metode pembelajaran yang sesuai dengan materi serta inovatif dalam melakukan kegiatan-kegiatan ilmiah yang menunjang kualitas kinerja dosen. Ini sesuai dengan penelitian Murwaningsih \& Wulandari (2011) bahwa lesson study dapat meningkatkan kualitas pembelajaran statistik.

Manfaat dari kegiatan lesson study pada penelitian ini adalah dosen dapat 
meningkatkan kembali pengetahuan serta dapat mengkaji pembelajaran seperti apa yang cocok bagi mahasiswa. Pembelajaran disini adalah pemilihan metode yang tepat. Selain itu juga dapat meningkatkan pembelajaran yang bermanfaat bagi mahasiswa. Dari sini diharapkan dosen dapat memikirkan tujuan jangka panjang setelah lesson study berakhir yang akan dicapai oleh mahasiswa. Manfaat ini didukung oleh penelitian Madawati (2015) yang sama-sama menunjukkan manfaat lesson study bagi kualitas pembelajaran dosen. Namun di dalam penelitian ini peneliti tidak hanya melihat dari kualitas pembelajaran namun juga pada kinerja dosen.

\section{KESIMPULAN}

Kesimpulan dari penelitian ini adalah dengan implementasi kegiatan lesson study dapat meningkatkan kinerja dosen matematika di STMIK Duta Bangsa pada proses perkuliahan. Hal tersebut ditunjukkan dengan hasil penelitian yang menunjukkan adanya peningkatan dari siklus I ke Siklus II.

Hal ini dapat dilihat dari indikator kemampuan dosen antara lain mampu merencanakan pembelajaran, mengelola kelas, memilih materi dan alat evaluasi, memilih metode dan media pembelajaran, memanfaatkan teknologi informasi, dan memiliki sikap positif terhadap pembelajaran serta memiliki semangat kolegalitas yang tinggi. Selain itu, partisipasi dosen selama pelaksanaan lesson study menunjukkan tingkat partisipasi yang cukup baik seperti ikut serta dalam merencanakan pembelajaran, melaksanakan pembelajaran, dan mengevaluasi kegiatan pembelajaran. Semua dilakukan secara bersiklus.

Implementasi lesson study memberikan dampak yang sangat baik pada kinerja dosen dalam pelaksanaan pembelajaran, hal tersebut dikarenakan dengan adanya diskusi dengan dosen lain baik sebelum pembelajaran, saat pembelajaran sampai setelah pembelajaran sehingga dosen model dapat mengetahui kekurangannya dalam pembelajaran dan dapat memperbaiki kekurangannya pada pertemuan berikutnya. Sedangkan dampak pada observer (dosen lain) dapat mengambil pengetahuan dari dosen lain yang dinilai baik untuk dapat diterapkan di dalam kelasnya.

\section{REFERENSI}

Lewis, Catherine C. 2002. Lesson study: AHandbook of Teacher-Led InstructionalChange. Philadelphia, PA: Study forBetter Schools, Inc.

Madawati, Mahar Yani. 2015. Penerapan Lesson Study pada Program Studi Pendidikan Matematika STKIP PGRI Pasuruan. Prosiding Seminar Nasional Matematika dan Pendidikan Matematika UMS.

Murwaningsih, Utami\&Wulandari, Andika Ayu. 2011. Penerapan Lesson Study di 
Program Studi Pendidikan Matematika

FKIP Universitas Veteran Bangun

Nusantara Sukoharjo. Seminar Hasil

Penelitian dan Pengabdian kepada

Masyarakat Tahun 2011

Nudji, DA. 2014. Upaya Meningkatkan Kemandirian Belajar Mahasiswa PPKN melalui Lesson Study. Jurnal Yudharta. http://jurnal.yudharta.ac.id/wpcontent/uploads/2014/09/UPAYAMENINGKATKAN-KEMANDIRIANBELAJAR-MAHASISWA-PPKNMELALUI-PEMBELAJARANLESSON-STUDY.pdf

Padlurrahman \& Novianti, Baiq Ariani. 2015. Peningkatan Kompetensi Dosen melalui Lesson Study pada Program Stui Pendidikan Fisika STKIP Hamzanwadi di Selong. Jurnal EducatiO Vol. 8 No.1, Juni 2015 , Hal81-94. http://download.portalgaruda.org/article.p hp? article $=401616 \& \mathrm{val}=8802 \&$ title $=$ PE NINGKATAN\%20KOMPETENSI\%20D OSEN\%20MELALUI\%20LESSON\%20 STUDY\%20PADA $\% 20$ PROGRAM $\% 20$ STUDI\%20PENDIDIKAN\%20FISIKA \%20STKIP\%20HAMZANWADI\%20SE $\underline{\mathrm{LONG}}$

Subadi, Tjipto. 2009. Pengembangan Model untuk Meningkatkan Kualitas Guru melalui Pelatihan Lesson Study di Sekolah Dasar Kota Surakarta. JurnalSekolah Dasar Kajian Teori dan PraktikPendidikan. Tahun 18. Nomor 2November 2009. ISSN 08548285.Malang: UN Malang.

Subadi, Tjipto. 2015. Peningkatan Profesional Dosen melalui Program Perluasan Lesson Study pada Jurusan IPS MIPA dan Biologi FKIP Universitas Muhammadiyah Surakarta. https://publikasiilmiah.ums.ac.id/bitstrea m/handle/11617/7370/MODEL\%20PEM BINAAN\%20DOSEN.pdf?sequence $=1$ 